\title{
REKONSTRUKSI INTERIOR BANGUNAN SEJARAH OPTIK SURYA DENGAN MODEL 3D
}

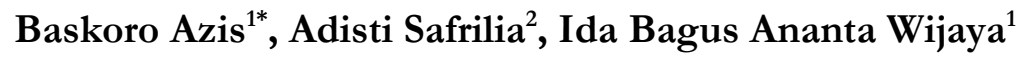 \\ ${ }^{1}$ Desain Interior, Sekolah Desain, Universitas Bina Nusantara, Araya Mansion No. 8 - 22, Genitri, \\ Tirtomoyo, Kec. Pakis, Malang, 65154 \\ ${ }^{2}$ Arsitektur, Teknik, Universitas Merdeka Malang, Jl. Puncak Jaya, Pisang Candi, Kec. Sukun, Kota \\ Malang, Jawa Timur, 65145 \\ *baskoro.azis@binus.ac.id
}

\begin{abstract}
ABSTRAK
Bangunan bersejarah di Kota Malang merupakan salah satu peninggalan bersejarah yang menjadi bukti penjajahan. Optik Surya merupakan salah satu bangunan bersejarah yang dibiarkan karena perawatan bangunan yang mahal sehingga menyebabkan bangunan tersebut terlihat lusuh di Kota Malang. Pelestarian dan rekosntruksi pada bangunan bersejarah terutama pada interior masih belum seimbang dengan eksteriornya. Maka perlu diadakan pelestarian dengan metode rekonstruksi 3D interior pada bangunan Optik Surya dengan menganalisa elemen desain dan prinsip desain untuk mengetahui ciri khas bangunan. Metode yang digunakan adalah kualitatif deskriptif, dengan mengumpulkan data observasi lapangan, tinjauan pustaka dan data visual. Hasil temuan berupa elemen bentuk, elemen pencahyaan dan warna yang paling mendominasi pada perbandingan antara elemen dan prinsip desain interior bangunan bersejarah Optik Surya dengan suasana pada tahun 1973 dan masa sekarang.
\end{abstract}

Kata kunci: Interior, Elemen Desain, Prinsip Desain, 3D, Rekonstruksi.

\begin{abstract}
Historical buildings in Malang city is one of the historical relics that became evidence of colonialism. Optik Surya is one of the historical buildings that are left because of the expensive maintenance of the building that causes the building to look shabby in Malang. Preservation and reconstruction of historic buildings, especially in the interior is still not balanced with the exterior. Then it is necessary to hold preservation with 3D interior reconstruction method in Surya Optical building by analyzing design elements and design principles to know the characteristics of the building. The method used is descriptive qualitative, by collecting field observation data, library reviews and visual data. The findings in the form of shape elements, elements of discoloration and color that dominate the comparison between elements and principles of interior design of historic buildings Surya Optics with the atmosphere in 1973 and the present.
\end{abstract}

Keywords: Interior, Element Design, Principles Design, 3D, Reconstruction. 


\section{PENDAHULUAN}

Pemilihan Kota Malang sebagai objek dalam penelitian ini, selain sebagai kota kedua yang terbesar di Jawa Timur, dan juga pertumbuhan kotanya yang sangat menakjubkan pada awal abad ke 20. Kota Malang sering disebut sebagai salah satu hasil perencanaan kota kolonial yang terbaik di Hindia Belanda pada jamannya (Handinoto, 1996). Banyak peninggalan arsitektur kolonial di Kota Malang yang sampai sekarang masih berdiri megah.

Namun saat ini, keberadaan bangunan bersejarah di Kota Malang masih kurang mendapat perhatian. Terjadinya vandalisme pada bangunan yang tidak terawat karena ditinggalkan pemiliknya, dan di jual pada pengusaha yang tidak peduli dengan keaslian bangunan kolonial dengan mengubah tampak bangunannya menjadi bangunan modern. Koridor Kayutangan yang menjadi kawasan bersejarah sebagai pusat perdagangan di Kota Malang dan jalan utama di masa lalu, kini bangunan bersejarahnya mulai tersamar dengan tampilan bangunan baru termasuk interiornya.

Pada era modern saat ini, masyarakat hanya menikmati bangunan bersejarah dari tampak dan bentuk bangunannya saja, mereka tidak bisa dengan bebas untuk mengakses bagian interior bangunan bersejarah tersebut, padahal interior bangunan bersejarah tidak kalah menarik untuk diamati. Interior pada bangunan bersejarah dapat menjadi pengalaman ruang yang baru untuk masyarakat karena dapat merasakan bangunan bersejarah di zaman modern serta dapat meningkatkan ketertarikan dan pengalaman untuk wisatawan.

Sudah banyak pelestarian terhadap eksterior bangunan dan untuk interior belum ada pelestariannya. Sehingga untuk memberikan pelestarian pada interior bangunan bersejarah, perlu dilakukan rekonstruksi menggunakan 3D pada interior bangunan bersejarah yang telah rusak. Guna menjaga bangunan-bangunan bersejarah tersebut agar dapat menjadi dokumentasi digital dan tidak hilang keberadaannya oleh zaman terutama interior bangunannya, perlu dilakukan pelestarian bangunan dengan metode rekonstruksi dan konservasi (Sujadi et al., 2018). Rekonstruksi yang dilakukan menggunakan 3D Rendering dan mengacu pada dokumentasi terdahulu bangunan yang masih asli berupa foto dan narasumber yaitu pemilik gedung. Pendokumentasian tersebut tidak hanya sebatas untuk sekedar mencari tahu dimensi geometri bangunan tetapi juga terkait dengan seberapa besar perubahan dimensi geometri bangunan yang terjadi dalam kurun waktu tertentu.

Objek bangunan yang dipilih pada penelitian ini adalah bangunan Optik Surya, salah satu bangunan bersejarah di Kayutangan. Bangunan tersebut dipilih karena interior bangunan dan furniture masih asli dan mengalami sedikit perubahan. 


\section{METODE PENELITIAN}

Metode yang digunakan dalam penelitian ini adalah metode kualitatif historical research dan deskriptif. Pada hakikatnya historical research ini adalah untuk menggambarkan atau memotret keadaan atau kejadian masa lalu yang kemudian digunakan untuk menjadi proses pembelajaran masyarakat sekarang. Sedangkan kualitatif deskriptif adalah suatu metode dalam meneliti status sekelompok manusia, atau objek, dengan membuat deskripsi, gambaran secara sistematis, faktual, dan akurat mengenai fakta-fakta atau fenomena yang diselidiki.

1) Observasi Lapangan dan Dokumentasi

Dari observasi lapangan bertujuan mengetahui kondisi riil pada tahun 1973 mengenai eksisting objek penelitian, khususnya pada ukuran ruang interior, perletakan furnitur dan elemen desain. Dokumentasi untuk mendapatkan gambaran pada interior bangunan Optik Surya pada saat tahun 1973 sebagai rekonstruksi 3D nantinya.

2) Wawancara

Wawancara dilakukan pada pemilik bangunan Optik Surya yang merupakan keturunan langsung untuk mendapatkan data mengenai denah dan perletakan furnitur pada tahun 1973.

3) Studi Pustaka

Tujuan dari studi ini adalah untuk memperoleh kajian mengenai hal-hal yang perlu diperhatikan dalam perancangan interior bangunan bersejarah.

4) Variabel Terpilih

Virtual Room Tour pada rekonstruksi interior bangunan bersejarah optik surya tidak lepas dari masyarakat, pemerintah, akademisi dan praktisi. Untuk mencapai penelitian yang baik, maka diperlukan adanya penilaian. Terdapat beberapa variabel yang akan dianalisis untuk membuktikan penelitian tentang pengalaman ruang responden dengan merekonstruksi bangunan bersejarah Optik Surya melalui virtual room tour. Variabel penelitian tersebut disesuaikan dengan literatur penelitianan terdahulu. Variabel tersebut adalah sebagai berikut. (Askari et al., 2014; Azis et al., 2015, 2019; Fauziah et al., 2012; Mackinnon et al., 2011; Manurung, 2015; Runa, 2016; Santosa, 2012; SANTOSA et al., 2013, 2014)
a) Bentuk
b) Warna
c) Motif
d) Keseimbangan
e) Pencahayaan
f) Keharmonisan
g) Proporsi

A. Metode Analisa Data 
Tahapan ini menganalisa data yang diperoleh di lapangan dan dokumentasi, berhubungan dengan kajian teoritis, dan kemudian dianalisa kembali, dari hasil analisa ini kemudian menghasilkan jawaban hasil analisa, yang selanjutnya disimpulkan menjadi hasil pengamatan rekonstruksi 3D interior bangunan bersejarah Optik Surya.

\section{HASIL DAN PEMBAHASAN}

\section{Denah dan Zonasi Bangunan Bersejarah Optik Surya tahun 1973}

Pembahasan merupakan bagian terpenting dari keseluruhan isi artikel ilmiah. Tujuan pembahasan ialah menjawab permasalahan penelitian, menafsirkan temuan-temuan, mengintegrasikan temuan dari penelitian ke dalam kumpulan pengetahuan yang telah ada, ataupun menyusun teori baru atau memodifikasi teori yang sudah ada.
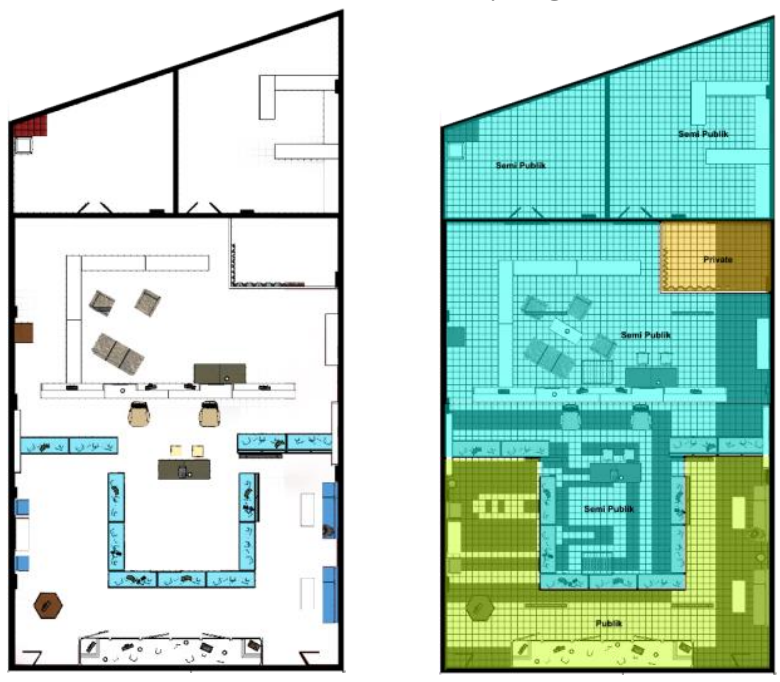

Gambar 1. Pembagian Area (kiri) dan Zonasi (kanan) Optik Surya 1973 (sumber: dokumentasi pribadi)

Secara garis besar perkembangan arsitektur kolonial di Malang tidak berbeda dengan perkembangan arsitektur di Hindia Belanda pada kurun waktu yang sama. Gaya arsitektur dan interior pada saat 1930 sekarang masih menggunakan gaya hindia belanda "Indische Empire" karena tidak mengalami perubahan sama sekali. Furniture maupun dinding ruangan dan juga warna yang dipakai hampir keseluruhan adalah warna netral seperti coklat dan putih serta aksen warna biru. Suasana uang menonjol adalah bersih, hangat, fresh dan kekeluargaan. 


\section{Layout dan Furniture}

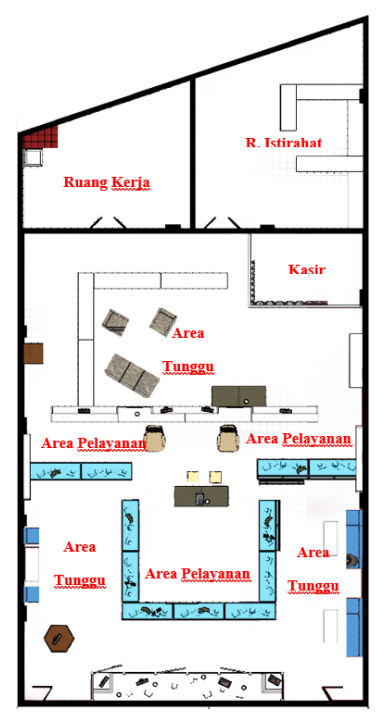

Gambar 2. Layout (sumber: dokumentasi pribadi)

\section{Rekonstruksi 3D Interior Rendering Bangunan Optik Surya}

Rekonstruksi diawali dari proses identifikasi interior ruang sebelumnya yang diperoleh dari foto dokumentasi tahun 1973 dan eksisting saat ini (2021). Gambar 3 merupakan gambar eksisting pada tahun 1973 dari dokumentasi foto. Sedangkan gambar 4 merupakan gambar eksisting saat ini (2021) lantai, dinding, dan plafon.
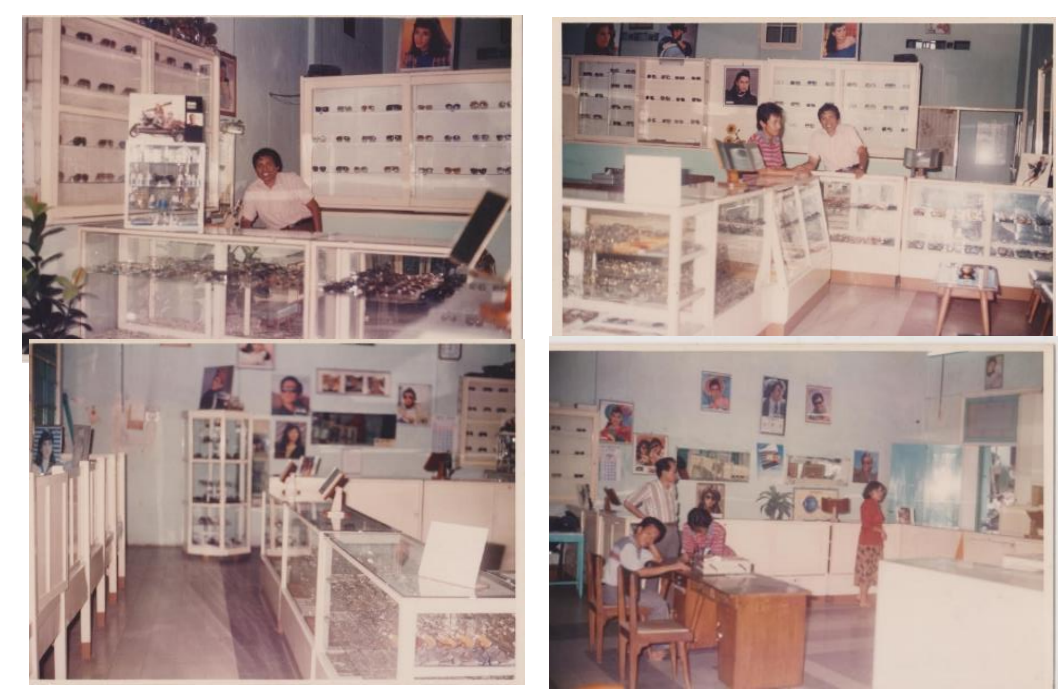

Gambar 3. Foto tahun 1973 Suasana Interior Optik Surya (sumber: dokumentasi Pak Faisal) 
Kondisi interior bangunan dari kurun waktu 1973-2021 tidak banyak yang berubah
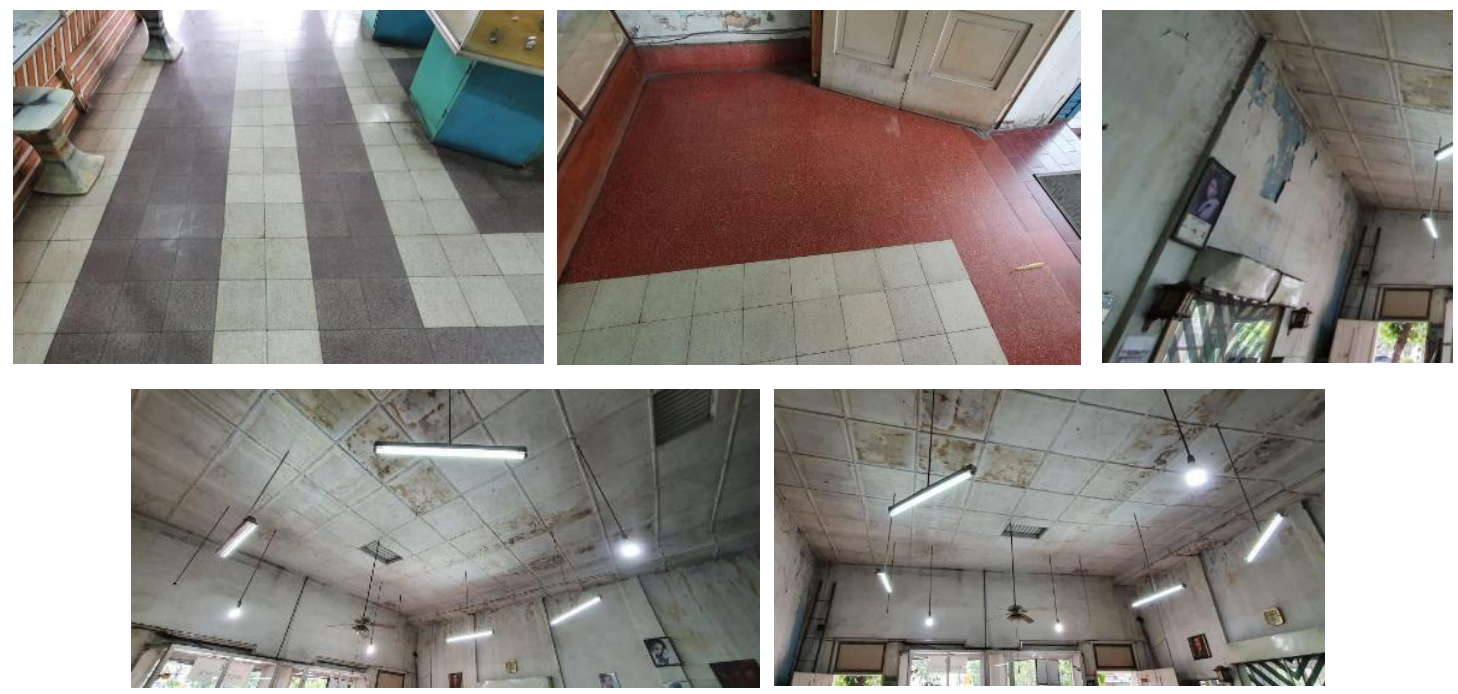

Gambar 4. Keadaan Sekarang (2021) (sumber: dokumentasi Pribadi)

\section{Hasil Rekonstruksi 3D Interior Bangunan Optik Surya Lantai}

Tegel yang digunakan pada bangunan Optik Surya adalah tegel semen (cement tiles). Material klasik ini banyak dijumpai di rumah-rumah zaman dulu. Lantai ini terbuat dari campuran semen dan pasir. Penggunaan lantai ini digunakan pada ruang pelayanan, ruang kerja, dan ruang istirahat. Penggunaan material lantai ini masih digunakan sampai saat ini dengan 3 motif dan warna berbeda, yaitu warna merah tua, merah, dan putih tulang. Lantai yang digunakan ubin PC polos dengan ukuran 20x20 cm. Penelitian sejenis memiliki kesamaan bahan pada lantai yaitu (Askari et al., 2014; Laksmi Kusuma Wardani \& Avelea Isada, 2009; Rustamaji, 2019; Sarjiyanto, 2017). Sehingga dapat disimpulkan bahwa pada bangunan bersejarah bergaya eropa "Indische Empire" memakai lantai bebahan tegel/ubin dari tanah liat.
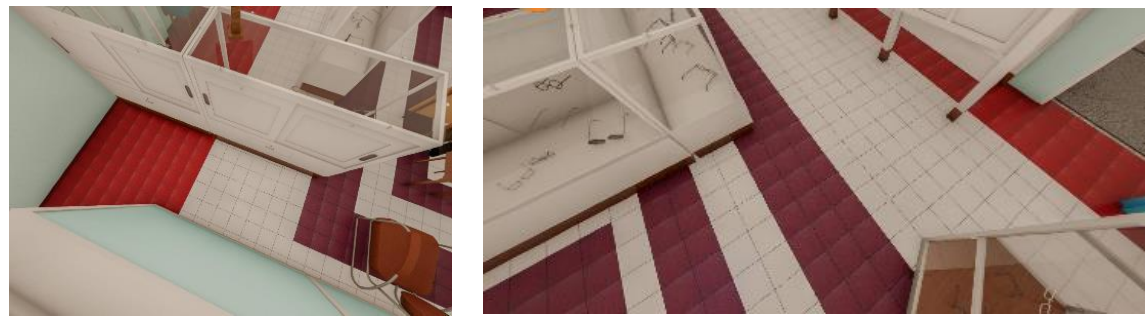

Gambar 5. Gambar 3D Lantai warna merah, putih dan merah tua (sumber: dokumentasi Pribadi) 


\section{Dinding}

Dinding bangunan Optik Surya secara keseluruhan menggunakan dinding batu bata merah dan plester dengan Warna yang digunakan untuk dinding ini biru muda. Dominasi warna biru muda memberikan kesan monumental yang merupakan salah satu ciri bangunan dengan gaya "Indische Empire". Terdapat dua jenis ketebalan dinding yang terdapat pada bangunan Optik Surya. Untuk dinding dan kolom bangunan peninggalan kolonial Belanda adalah dinding satu bata $\pm 30 \mathrm{~cm}$ sedangkan dinding pembantas dengan luar dinding pasangan setengah bata $\pm 15 \mathrm{~cm}$. Dinding setengah bata digunakan pada bangunan Optik Surya, yaitu Ruang Pelayanan, Ruang Kerja, dan Ruang Istirahat. Dinding bangunan utama merupakan dinding bata berukuran satu bata, plester dan finishing warna biru muda serta tidak memiliki ornamen sama sekali. Pada beberapa peneliti menyebutkan bahwa pada bangunan bersejarah rata-rata menggunakan material batu bata dan finishing plaster (Laksmi Kusuma Wardani \& Avelea Isada, 2009; Sarjiyanto, 2017). Dinding bangunan utama bangunan memiliki tekstur yang halus. Dinding ini juga memiliki elemen lain yaitu jendela dan pintu yang terbuat dari kayu dan kaca.

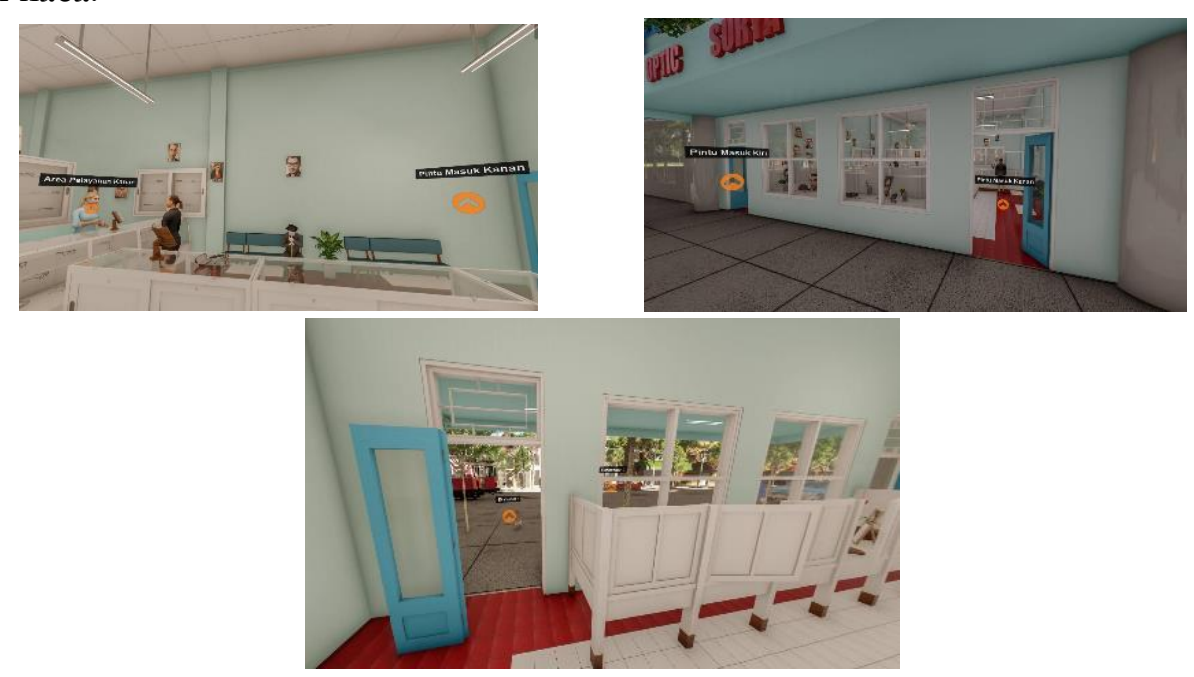

Gambar 6. Gambar 3D jendela, dinding, pintu dan ventilasi (sumber: dokumentasi Pribadi)

\section{Plafon}

Plafon bangunan Optik Surya terbuat dari bahan lembaran kayu yang dicat bewarna putih serta memiliki pola persegi yang menonjol. Terdapat angin-angin dan berfungsi sebagai pencahayaan juga. Sampai saat ini, plafon masih tetap utuh tidak berubah hanya adanya penutupan angin-angin di plafon karena keamanan untuk terhindar dari pencuri dengan menggunakan teralis dan penutup tambahan. Pada plafon bangunan Optik Surya memiliki tinggi antara 4,5 - 5 meter. Pada penelitian yang lain memiliki pendapat yang sama terhadap 
bangunan bersejarah yaitu memiliki plafon yang tinggi (Laksmi Kusuma Wardani \& Avelea Isada, 2009; Rustamaji, 2019). Disaat yang bersamaan, terdapat perbedaan pendapat terhadap motif pada plafon yaitu pada bangunan bersejarah umumnya memakai balok kayu dan tertutup rata polos tanpa motif (Laksmi Kusuma Wardani \& Avelea Isada, 2009). Hal ini berbanding terbalik dengan bangunan Optik Surya.
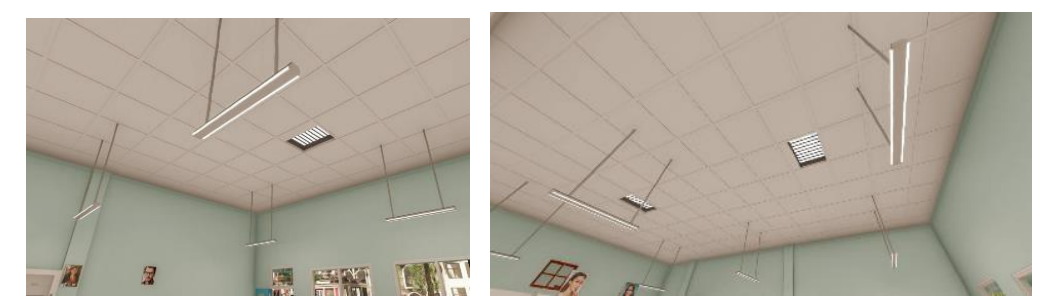

Gambar 7. Gambar 3D plafon yang menonjol dan lampu neon horisontal (sumber: dokumentasi Pribadi)

\section{Bentuk}

Bentuk yang lebih dominan adalah bentuk persegi, persegi panjang, dengan garis dominan horisontal dan vertikal secara seimbang. Yang lebih menonjol adalah bentukan pada furniturnya yaitu persegi panjang.
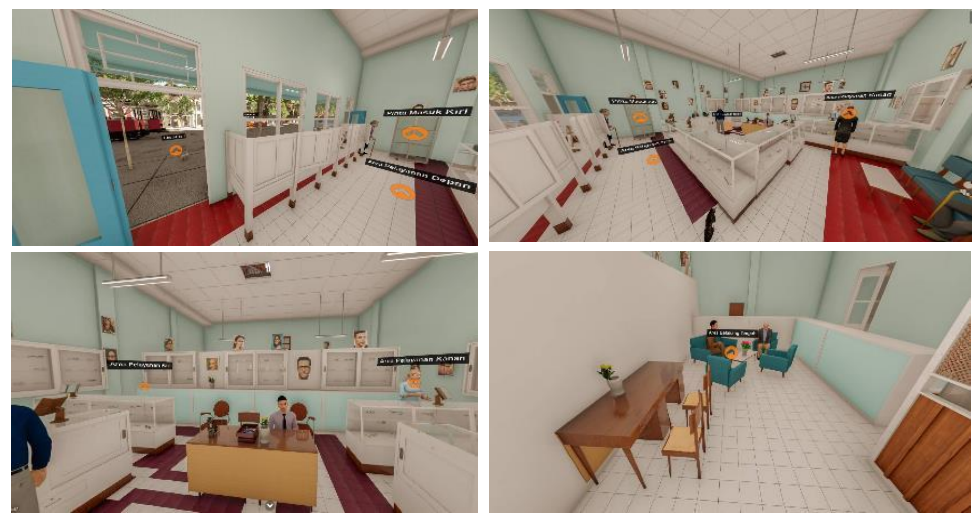

Gambar 8. Gambar 3D bentuk jendela, pintu, perabot dominan bentuk kubus dan balok (sumber: dokumentasi Pribadi)

\section{Warna}

Warna yang ditampilkan pada bangunan ini adalah warna biru muda pada dingding, dan yang paling dominan adalah warna putih dan aksen kayu coklat pada furnitur display kacamata. Pada lantai warnanya seimbang antara warna merah, merah tua, dan putih tulang. 


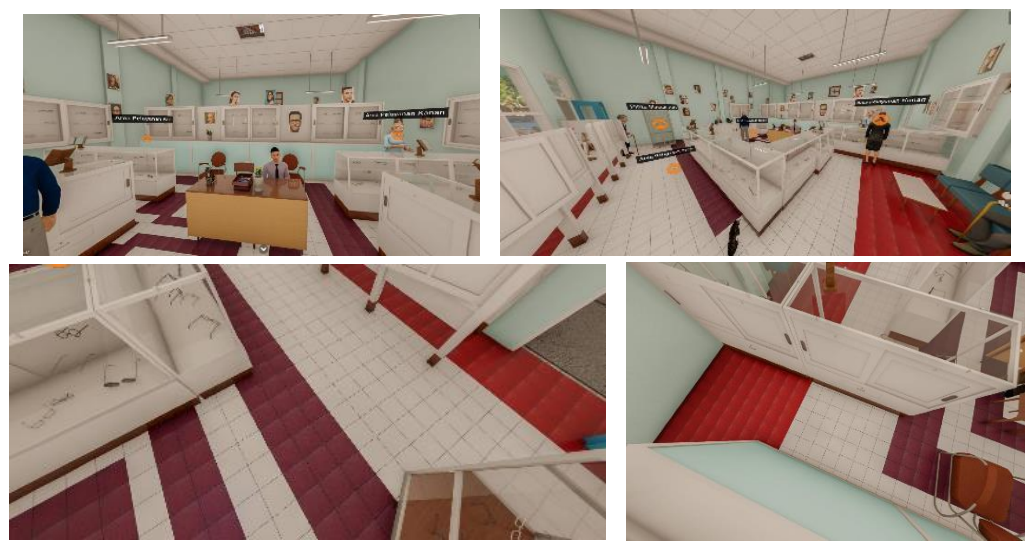

Gambar 9. Gambar 3D warna dominan pada interior Optik Surya (sumber: dokumentasi Pribadi)

\section{Motif}

Motif yang terlihat menonjol adalah pada lantai berupa bintik-bintik warna merah-merah tua dan plafon dengan pola menonjol.
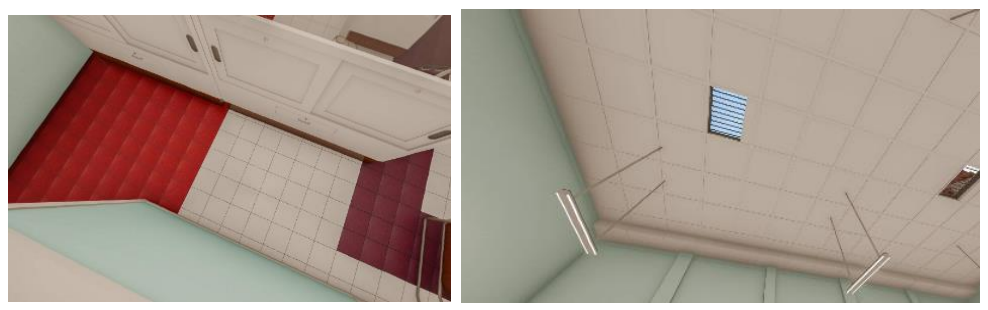

Gambar 10. Gambar 3D Pola titik pada lantai dan persegi menonjol pada plafon (sumber: dokumentasi Pribadi)

\section{Keseimbangan}

Keseimbangan asimetris pada visual terdapat pada interior ruangan dan pada setiap furnitur.

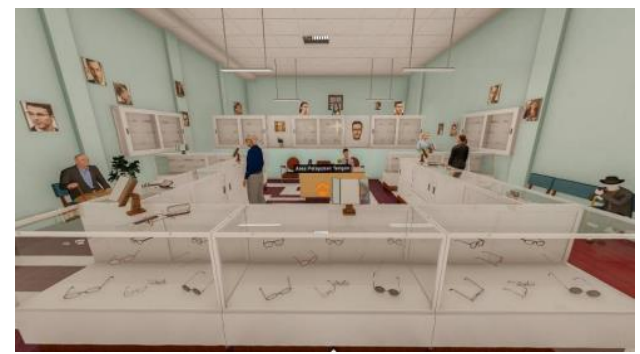

Gambar 11. Gambar 3D Interior Optik Surya (sumber: dokumentasi Pribadi)

\section{Pencahayaan}


Pencahayaan terbagi menjadi dua bagian, yaitu pencahayaan alami dan buatan. Pencahayaan alami dibantu oleh bukaan jendela dan pintu. Sedangkan pencahayaan alami dengan banyaknnya lampu neon memanjang di plafon.
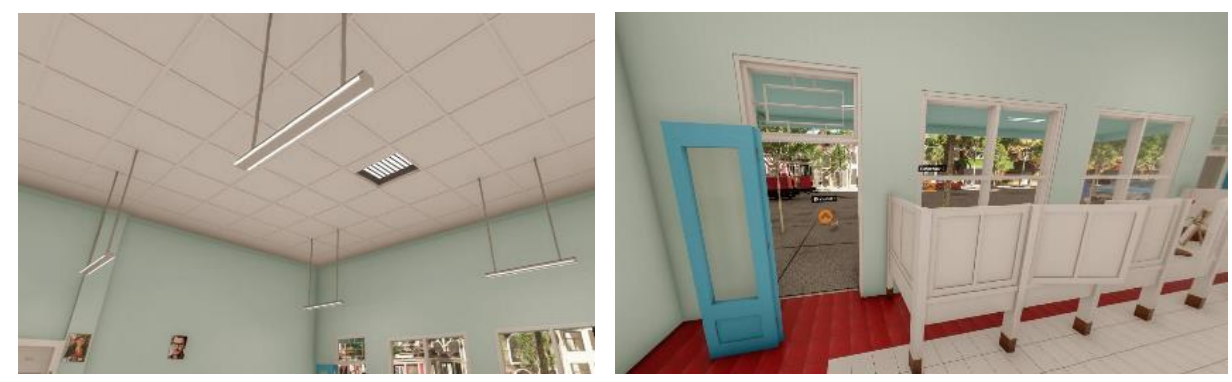

Gambar 12. Gambar 3D Pencahayaan Buatan dan Alami (sumber: dokumentasi Pribadi)

\section{Keselarasan}

Keselarasan pada interior dapat dilihat dari keseluruhan yang terdapat pada interior yaitu, lantai, dinding, plafon, dan furnitur dengan warna netral dan bentuk sebagai kesinambungan. (dapat dilihat pada Gambar 11)

\section{Proporsi}

Ukuran furnitur dan ukuran ruang mengakibatkan ruangan terlihat berat secara vertikal (fokus ke furniture) dan terlihat luas secara horisontal. (dapat dilihat Gambar 11 dan 13)

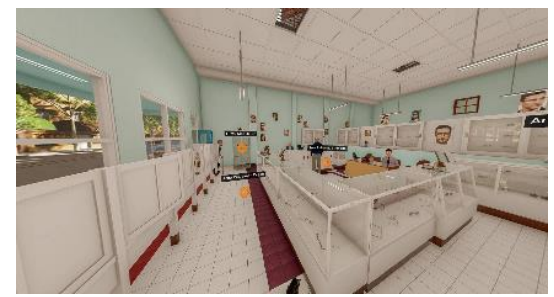

Gambar 12. Gambar 3D Perspektif dari pintu masuk kanan bangunan (sumber: dokumentasi Pribadi)

\section{SIMPULAN}

Dari hasil studi literatur, dokumentasi dan pembahasan rekonstruksi 3D Optik Surya tahun 1973 dibandingkan dengan zaman sekarang terjadi perubahan elemen dan prinsip desain pada bentuk (plafon dan furniture), pencahayaan dan warna. Hal tersebut karena kebutuhan pemilik. Dasar perubahan ini karena perubahan kebutuhan masyarakat dan daya saing yang cukup kompetitif serta perawatan bangunan yang mahal. 
Jika dilihat dari segi elemen desain, elemen yang paling menonjol adalah elemen garis vertikal dan horisontal. Pada elemen bidang yang paling menonjol adalah bidang persegi dan persegi panjang. Pada elemen bentuk yang menonjol adalah bentuk kubus. Yang menjadi ciri khas pada gedung ini adalah keseimbangan visual pada interior. Yang menjadi daya tarik interior bangunan bersejarah Optik Surya adalah furnitur yang menjadi pusat perhatian karena ukuran dan keselarasan bangunan dengan latar belakang ruangan dinding dan plafon setinggi empat sampai lima meter.

Untuk pencahayaan mengalami pemerataan cahaya antara bagian depan dan ke arah belakang bangunan dengan menggunakan pencahayan buatan dan ketika menggunakan pencahayaan alami mengalami degradasi cahaya dari area pelayanan ke area tunggu. Sedangkan untuk plafon mengalami penambahan berupa teralis besi karena sudah rawan akan kejahatan pencurian pada malam hari.

\section{REFERENSI}

Askari, A. H., Dola, K. B., \& Soltani, S. (2014). An evaluation of the elements and characteristics of historical building façades in the context of Malaysia. Urban Design International, 19(2), 113-124. https://doi.org/10.1057/udi.2013.18

Azis, B., Asikin, D., \& Laksmiwati, T. (2015). Interior ruang kelas dan bengkel kerja dengan pemanfaatan barang bekas otomotif di smk kota malang. Jurnal Mahasiswa Jurusan Arsitektur, 3(1).

Azis, B., Santosa, H., \& Ernawati, J. (2019). Assessing Public Perception for Illumination of Building in Kayutangan Street, Malang, Indonesia. DIMENSI (Journal of Architecture and Built Environment), 46(1), 11-22. https://doi.org/10.9744/dimensi.46.1.11-22

Fauziah, N., Antariksa, A., \& Ernawati, J. (2012). Kualitas Visual Fasade Bangunan Modern Pasca Kolonial di Jalan Kayutangan Malang. Review of Urbanism and Architectural Studies, 10(2), 11-18. https://doi.org/10.21776/ub.ruas.2012.010.02.2

Handinoto. (1996). Perkembangan Kota \& Arsitektur Kolonial Belanda di Malang (1st ed.). Universitas Kristen PETRA dan Penerbit Andi.

Laksmi Kusuma Wardani, \& Avelea Isada. (2009). Gaya Desain Kolonial Belanda Pada Interior Gereja Katolik Hati Kudus Yesus Surabaya. Dimensi Interior, 7, 52-64.

Mackinnon, G., Hillier, du T. A., Brandson, H., \& Bray, C. (2011). Heritage Lighting Master Plan for Old Town Toronto. 1-110.

Manurung, P. (2015). Simposium Nasional RAPI XIV-2015 FT UMS. 1985, 8-12.

Runa, I. (2016). Konservasi Bangunan Bersejarah: Studi Kasus Bangunan Peribadatan di Pulau Bali. Undagi, 1-11.

Rustamaji, I.-. (2019). Pengaruh Gaya Arsitektur Bangunan Indis Terhadap Aspek Sosial Dan Budaya Masyarakat Kabupaten Boyolali. Haluan Sastra Budaya, 3(1), 47. https://doi.org/10.20961/hsb.v3i1.26408

Santosa, H. (2012). Study of visual preferences on the growth of urban commercial streetscape through building owners assesment. August, 1-16. https://doi.org/10.13140/2.1.2354.8807 
Santosa, H., Ikaruga, S., \& Kobayashi, T. (2013). Visual Evaluation of Urban Commercial Streetscape Through Building Owners Judgment. Journal of Architecture and Planning (Transactions of AIJ), 78(691), 1995-2005. https://doi.org/10.3130/aija.78.1995

S Santosa, H., Ikaruga, S., \& Kobayashi, T. (2014). Development of Landscape Planning Support System Using Interactive 3D Visualization. Journal of Architecture and Planning (Transactions of AIJ), 79(706), 2699-2709. https://doi.org/10.3130/aija.79.2699

Sarjiyanto. (2017). Penggunaan Ubin-Ubin Enkaustik: Studi Kasus Pada Beberapa Bangunan Abad Ke-19 Di Indonesia. 53-72.

Sujadi, D., Thajadi, M. E., \& Sai, S. S. (2018). 3D Modelling Obyek Kerapatan Tinggi Menggunakan Metode Fotogrametri Jarak Dekat (Studi Kasus: Patung Pandawa Perumahan Pandawa, Kota Malang). 